\title{
Tumor Necrosis Factor-Alpha Gene Expression in Human Whole Blood
}

\author{
Robert M. Strieter, Daniel G. Remick, John M. Ham, Lisa M. Colletti, \\ Joseph P. Lynch, III, and Steven L. Kunkel \\ Division of Pulmonary and Critical Care Medicine, Department of Internal Medicine (R.M.S., \\ J.P.L.), Department of Surgery, (J.M.H., L.M.C.) and Department of Pathology \\ (S.L.K., D.G.R.), The University of Michigan Medical School, Ann Arbor
}

\begin{abstract}
Tumor necrosis factor-alpha (TNF) is recognized as a principal mediator of a variety of pathophysiologic and immunologic events. Lipopolysaccharide (LPS) challenge, either in vitro or in vivo, results in significant TNF production. In this study we present data demonstrating LPS-induced TNF mRNA expression and bioactivity using an in vitro tissue system of whole blood (WB). The kinetics of LPS-induced TNF production by WB was significantly accelerated as compared to isolated cultured peripheral blood monocytes (PBM). At post-LPS challenge, plasma from WB demonstrated a rapid rise in TNF bioactivity, peaking by $4 \mathrm{hr}(1,021$ units/ml/10 cells), plateauing between 4 and $8 \mathrm{hr}$, and then decreasing over the next $16 \mathrm{hr}$. In contrast, the highest measured TNF bioactivity from PBM did not occur until the 24-hr time-point (175 units/ml/10 cells). Whole blood butfycoat TNF mRNA was assessed by Northern blot analysis, and demonstrated significant TNF mRNA accumulation at $1 \mathrm{hr}$ and a peak $2 \mathrm{hr}$ post-LPS challenge. By $8 \mathrm{hr}$ TNF mRNA was undetectable. Concomitant administration of LPS with either prostaglandin $E_{2}$ $\left(10^{-6} \mathrm{M}\right)$ or Dexamethasone $\left(10^{-6} \mathrm{M}\right)$ resulted in significant suppression of LPS-induced TNF production. This data supports WB as a useful in vitro medium for the molecular and cellular analyis of TNF. As specialized connective tissue, WB may provide an important environment to study the pharmacologic manipulation of TNF mRNA and bioactivity.
\end{abstract}

Key words: monocytes, inflammation, cytokines

\section{INTRODUCTION}

Tumor necrosis factor-alpha (TNF) is a mononuclear phagocyte-derived cytokine that may orchestrate a variety of physiological and immunological events $[1,2]$. At the cellular level, TNF has diverse effects on a variety of cell types and serves as an effective signal for cell-to-cell communication [3-9]. At the systemic level, TNF plays a significant role in promotion of cachexia and mediation of septic shock $[10,11]$. Human-derived TNF has been studied both in vivo and in vitro post-lipopolysaccharide (LPS) challenge $[12,13]$. The production of human TNF has been documented in vivo both clinically, septic patients [13], and experimentally, after normal subjects received systemic LPS [14]. In vitro the majority of data regarding the synthesis and regulation of human TNF has been generated using primary cells in culture or tumor lines $[12,15]$. Although these systems have provided valuable approaches in studying the production and regulation of TNF, they both have inherent limitations. In order to bridge the in vivo and in vitro TNF studies, we have utilized whole blood as a system to assess the production and mRNA expression of human TNF. Since blood is defined as a specialized circulating connective tissue that communicates with other organs/tissues [16], we have used this medium to: 1) examine the production of biologically active TNF and compare this with TNF levels from monolayers of peripheral blood monocytes, 2) assess TNF mRNA expression from the cellular constituents of intact whole blood, and 3) evaluate pharmacologic regulation of TNF bioactivity.

\section{MATERIALS AND METHODS}

\section{Recovery of Whole Blood and Isolation of} Peripheral Blood Monocytes

Peripheral blood was obtained by venipuncture from healthy human volunteers $(n=9)$. Five $\mathrm{ml}$ of heparin ized (50 USP units/ml) whole blood (WB) was aliquoted into $15 \mathrm{ml}$ conical tubes. Peripheral blood monocytes (PBM) from WB diluted 1:1 with normal saline were

Received June 23, 1989; accepted August 11, 1989.

Reprint requests: Steven L. Kunkel, Department of Pathology, The University of Michigan Medical School, 1301 Catherine Rd., Box 0602, Ann Arbor, MI 48109. 
separated by density centrifugation on Ficoll-Hypaque (Pharmacia, Piscataway, NJ). Isolated mononuclear cells were resuspended in sterile RPMI-1640 (Whitaker Biomedical Products, Whitaker, CA), $1 \mathrm{mM}$ glutamine, 25 mM HEPES, 100 units penicillin, $100 \mu \mathrm{g}$ streptomycin/ ml (Hazelton Research Products, Denver, PA) (complete media) and washed three times. Differential cell counts and viability analyses by trypan-blue exclusion were conducted for PBM. Peripheral blood monocytes $\left(10^{6}\right.$ cells $/ \mathrm{ml}$ ) were plated in $10 \mathrm{ml}$ volumes in $100 \mathrm{~mm}$ culture plates (Costar, Cambridge, MA) and incubated for 1 hr at $37^{\circ} \mathrm{C}$ in $95 \%$ air and $5 \% \mathrm{CO}_{2}$. Cells were washed twice with complete media for adherence enrichment. Total and differential cell counts for WB were performed. Whole blood in $15 \mathrm{ml}$ conical tubes was stimulated in a dose or kinetic fashion with specific reagents, then placed on a rocker at $37^{\circ} \mathrm{C}$ in $95 \%$ air and $5 \% \mathrm{CO}_{2}$. At specified times, WB was centrifugated at $600 \mathrm{~g}$ for 5 min. Plasma and buffy-coat (cells) were isolated for bioassay and nucleic-acid extraction, respectively. Cell-free supernatant from cultured PBM was removed for TNF assay and the adhered cells extracted for mRNA analysis.

\section{Reagents}

Prostaglandin $\mathrm{E}_{2}\left(\mathrm{PGE}_{2}\right)$ was the generous gift of the Upjohn Company. Stock $\mathrm{PGE}_{2}$ was prepared at a concentration of $10^{-2} \mathrm{M}$ in ethanol. Dexamethasone (Dex; Sigma Chemical Co., St. Louis, MO) stock was prepared at a concentration of $10^{-2} \mathrm{M}$ in dimethyl sulfoxide (DMSO). Serial dilutions of $\mathrm{PGE}_{2}$ and Dex were prepared in complete media. Lipopolysaccharide (Escherichia coli 0111:B4; Sigma Chemical Co.) stock was prepared at a concentration of $200 \mu \mathrm{g} / \mathrm{ml}$ in complete media.

\section{Tumor Necrosis Factor Bioassay}

Tumor necrosis factor bioactivity was measured in both the cell-free supernatants and plasma. Bioactivity of TNF was monitored using a semi-automated WEHI 164 subclone 13 fibrosarcoma lytic assay. WEHI cells were suspended $5 \times 10^{4}$ in $100 \mu \mathrm{l}$ of RPMI-1640,10\% fetal calf serum, $1 \mathrm{mM}$ glutamine, $0.5 \mu \mathrm{g} / \mathrm{ml}$ actinomycin $\mathrm{D}$, and plated in 96-well culture plates. Samples were serially diluted and $100 \mu \mathrm{l}$ added to each well. Plates were allowed to incubate for $20 \mathrm{hr}$ at $37^{\circ} \mathrm{C}$ in $95 \%$ air and $5 \%$ $\mathrm{CO}_{2}$. This was followed by the addition of $20 \mu$ l of MTT tetrazolium $(5 \mathrm{mg} / \mathrm{ml}$; Sigma Chemical Co.) for an additional $4 \mathrm{hr}$. One hundred fifty microliters of supernatant fluid was removed from each well and replaced with $100 \mu \mathrm{l}$ of isopropanol-0.04 N HCL to dissolve the tetrazolium crystals. Culture plates were then read in a microELISA reader at $540 \mathrm{~nm}$. Units of TNF were defined using an internal standard of human recombinant
TNF with a specific activity of 22 units/ng protein (Cetus Corp., Emeryville, CA). To allow comparison of TNF bioactivity between different experiments or between WB and PBM, TNF was further standardized to either the number of adherent monocytes (PBM) or absolute quantity of monocytes derived from the total cell and differential counts from WB. Rabbit anti-human TNF neutralizing antibody was used to establish specific TNFinduced cell lysis.

\section{Northern Blot Analysis of TNF mRNA}

Total RNA from PBM and WB buffy-coats was isolated as previously described [17]. Briefly, at specific time-points PBM and WB buffy-coats were placed into a solution of $25 \mathrm{mM}$ Tris, $\mathrm{pH} 8.0$, containing $4.2 \mathrm{M}$ guanidine isothiocyanate, $0.5 \%$ sarkosyl, and $0.1 \mathrm{M} 2$-mercaptoethanol. After homogenization, an equal volume of $100 \mathrm{mM}$ Tris, $\mathrm{pH} 8.0$, containing $10 \mathrm{mM}$ EDTA and $1.0 \%$ SDS was added and the mixture was extracted with chloroform-phenol and chloroform-isoamyl alcohol. The RNA was alcohol precipitated and the pellet dissolved in $10 \mathrm{mM}$ Tris/ $0.1 \mathrm{mM}$ EDTA (TE) buffer with $0.1 \%$ sarkosyl. RNA (10 $\mu \mathrm{g} / \mathrm{lane})$ was separated using formaldehyde $/ 1 \%$ agarose gels and transblotted to nitrocellulose. The blot was baked, prehybridized, and hybridized with ${ }^{32} \mathrm{P}-5^{\prime}$ end-labeled synthetic oligonucleotide probe for human TNF. The nucleotide sequence for TNF was the 25-mer 5'-GGT-CAC-CCT-TCT-CCA-GCT-GGAAGA-C-3' [18]. Blots were washed and autoradiographed with intensifying screens. Relative sensitivity of autoradiographs were quantitated using laser densitometry (Ultrascan XL, LXB Instruments, Inc., Houston, TX). Equivalent amounts of total RNA/gel were assessed by monitoring $28 \mathrm{~S}$ and $18 \mathrm{~S}$ rRNA.

\section{RESULTS}

\section{LPS-Induced TNF Bioactivity From WB and PBM}

The classical stimulus for induction of TNF at both the cellular and molecular level is LPS [1]. This stimulus was utilized as a primary challenge in our experiments. We first examined the dose-response of LPS-induced TNF bioactivity from both WB and PBM. Whole blood and PBM monolayers were incubated for $3 \mathrm{hr}$ post-LPS $(10 \mathrm{pg} / \mathrm{ml}$ to $10 \mu \mathrm{g} / \mathrm{ml}$ ) challenge. Concentrations of LPS above $10 \mathrm{ng} / \mathrm{ml}$ resulted in significant increases in TNF bioactivity from both WB and PBMs. TNF bioactivity was noted to be maximal with $10 \mu \mathrm{g} / \mathrm{ml}$ of LPS (data not shown). We next examined the kinetics of TNF production from WB and PBM after LPS stimulation. Both WB and PBM were challenged with $10 \mu \mathrm{g} / \mathrm{ml}$ LPS and either plasma or cell-free supernatant was removed at the designated times. As depicted in Figure 1A, kinetic analysis of LPS-induced TNF bioactivity from WB was deter- 

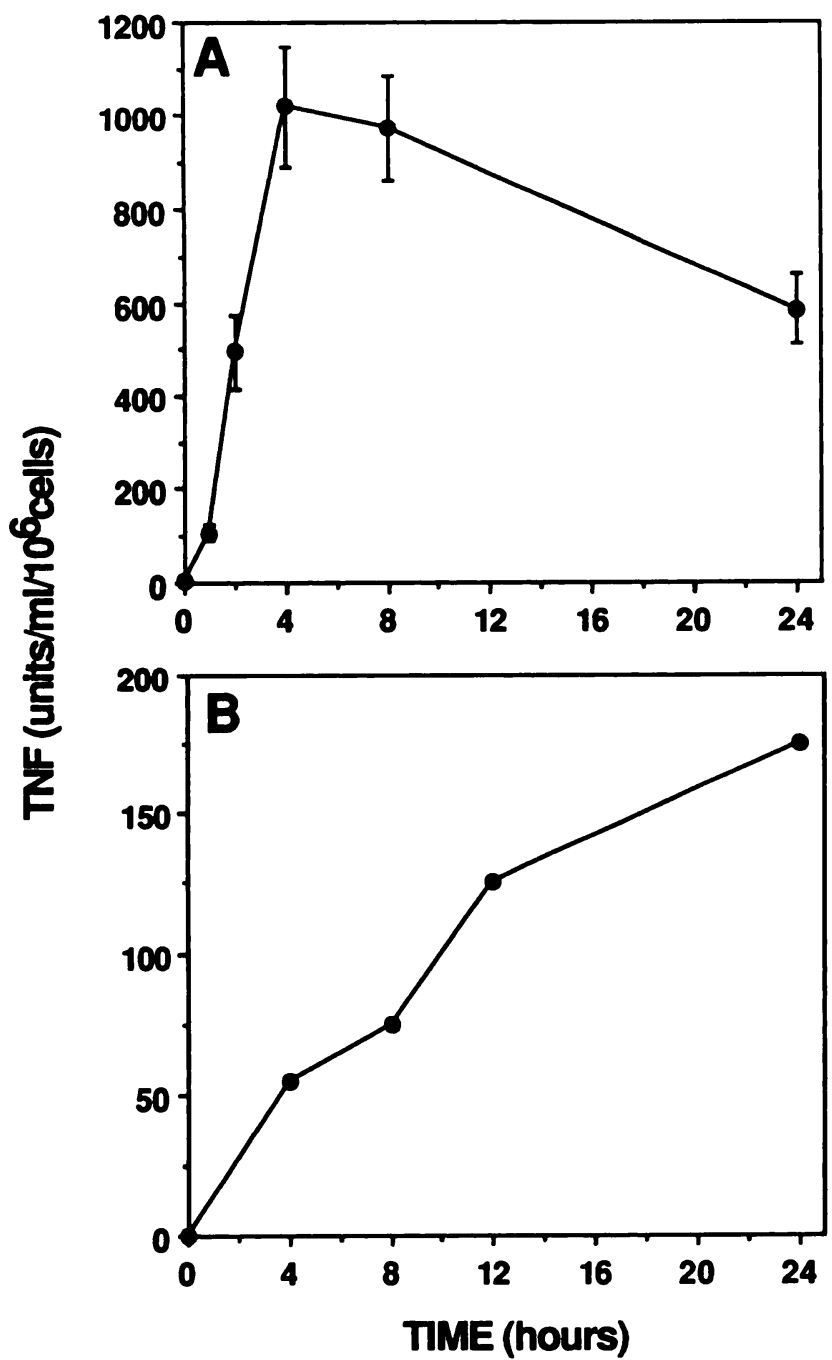

Fig. 1. The kinetic analysis of LPS-induced TNF bioactivity from WB and PBM. Whole blood and PBM were both challenged with LPS $(10 \mu \mathrm{g} / \mathrm{ml})$ and either plasma or cell-free supernatants were isolated and analyzed for TNF production at designated times. A: Whole blood TNF bioactivity from 9 subjects was significant at $1 \mathrm{hr}(107 \pm 17$ units/ml/10 cells), peak bloactivity at $4 \mathrm{hr}\left(1,021 \pm 128\right.$ units $/ \mathrm{ml} / 10^{6}$ cells $)$, with a plateau from 4 to 8 hr followed by a gradual decline (43\%) over the next $16 \mathrm{hr}$ to a TNF lovel of $585 \pm 73$ units $/ \mathrm{ml} / 10^{\circ}$ cells at $24 \mathrm{hr}$. Each time-point was statistically different from each other except 4 and $8 \mathrm{hr}(P$ $<0.05$ ). In contrast, $B$ is a representative kinetic analysis of TNF bloactivity from PBM $(n=4)$. TNF blosctivity was found to rise gradually throughout the study period with maximal TNF activity achleved at $24 \mathrm{hr}$ post-LPS challenge (175 units $/ \mathrm{ml} / 10^{\circ} \mathrm{cells}$ ).

mined from nine subjects. TNF levels were significant at $1 \mathrm{hr}\left(107 \pm 17\right.$ units $/ \mathrm{ml} / 10^{6}$ cells $)$, peaking at $4 \mathrm{hr}(1,021$ \pm 128 units $/ \mathrm{ml} / 10^{6}$ cells) with a plateau in bioactivity between 4 and $8 \mathrm{hr}$. This plateau in bioactivity was followed by a gradual decline (43\%) over the next $16 \mathrm{hr}$ to a TNF level of $585 \pm 73$ units $/ \mathrm{ml} / 10^{6}$ cells at $24 \mathrm{hr}$. Cellular viability after $24 \mathrm{hr}$ was established by exclusion of trypan-blue from buffy-coat cells ( $>90 \%$ ). To exclude a plasma inhibitor of TNF, plasma from time-points after $8 \mathrm{hr}$ were treated with exogenous recombinant human TNF. Plasma from these time-points failed to inhibit exogenous TNF. In contrast, Figure $1 \mathrm{~B}$ is a representative kinetic analysis of TNF bioactivity from PBM monolayer $(n=4)$. TNF bioactivity was found to rise gradually throughout the study period with maximal TNF activity being achieved at $24 \mathrm{hr}$ post-LPS challenge (175 units/ $\mathrm{ml} / 10^{6}$ cells). The $8 \mathrm{hr}$ time-point from PBM monolayer represented $<50 \%$ of the maximal TNF response at 24 $\mathrm{hr}$.

\section{WB-Derived TNF mRNA}

To examine TNF gene expression from WB, we next assessed LPS-induced TNF mRNA accumulation in a kinetic fashion from WB (buffy-coat cells). Whole blood $(5 \mathrm{ml})$ was stimulated with LPS $(10 \mu \mathrm{g} / \mathrm{ml})$ at time zero, and total RNA from the buffy-coat was extracted at specified times. Figure 2 demonstrates the Northern blot analysis of WB-derived TNF mRNA accumulation at specific times post-LPS addition. Each lane represents $10 \mu \mathrm{g}$ of total RNA loaded per well. TNF mRNA accumulation was significant at $1 \mathrm{hr}$, with a peak in TNF mRNA occurring at $2 \mathrm{hr}$ post-LPS challenge. TNF mRNA rapidly decayed after $2 \mathrm{hr}$, with essentially baseline levels achieved by $8 \mathrm{hr}(\mathrm{n}=4)$.

\section{Pharmacologic Suppression of TNF Bioactivity From WB}

To establish the efficacy of WB as a tool for monitoring pharmacologic manipulation of TNF production, both $\mathrm{PGE}_{2}$ and Dex were evaluated for their ability to suppress WB-derived TNF bioactivity. $\mathrm{PGE}_{2}$ and Dex at a concentration of $10^{-6} \mathrm{M}$ have been shown to inhibit mononuclear phagocytic cell TNF synthesis in vitro $[17,19]$. Whole blood $(5 \mathrm{ml})$ was incubated for $3 \mathrm{hr}$ in the presence of either LPS $(10 \mu \mathrm{g} / \mathrm{ml})$ alone, $\mathrm{PGE}_{2}\left(10^{-6} \mathrm{M}\right)$ concomitant with LPS, Dex $\left(10^{-6} \mathrm{M}\right)$ concomitant with LPS, or media alone. As shown in Figure 3, concomitan administration of either $\mathrm{PGE}_{2}$ or Dex resulted in a $91 \%$ and $80 \%$ suppression of LPS-stimulated WB-derived TNF bioactivity $(n=3)$, respectively. Neither $\mathrm{PGE}_{2}$ no Dex in concentrations utilized in these experiments was found to inhibit the activity of exogenous recombinan TNF in our WEHI bioassay.

\section{DISCUSSION}

Tumor necrosis factor-alpha (TNF) is increasingly recognized for its pleiotropic effects in immune and pathophysiologic events. It appears to be an essential cytokine at the cellular level, representing a pivotal signal in or 

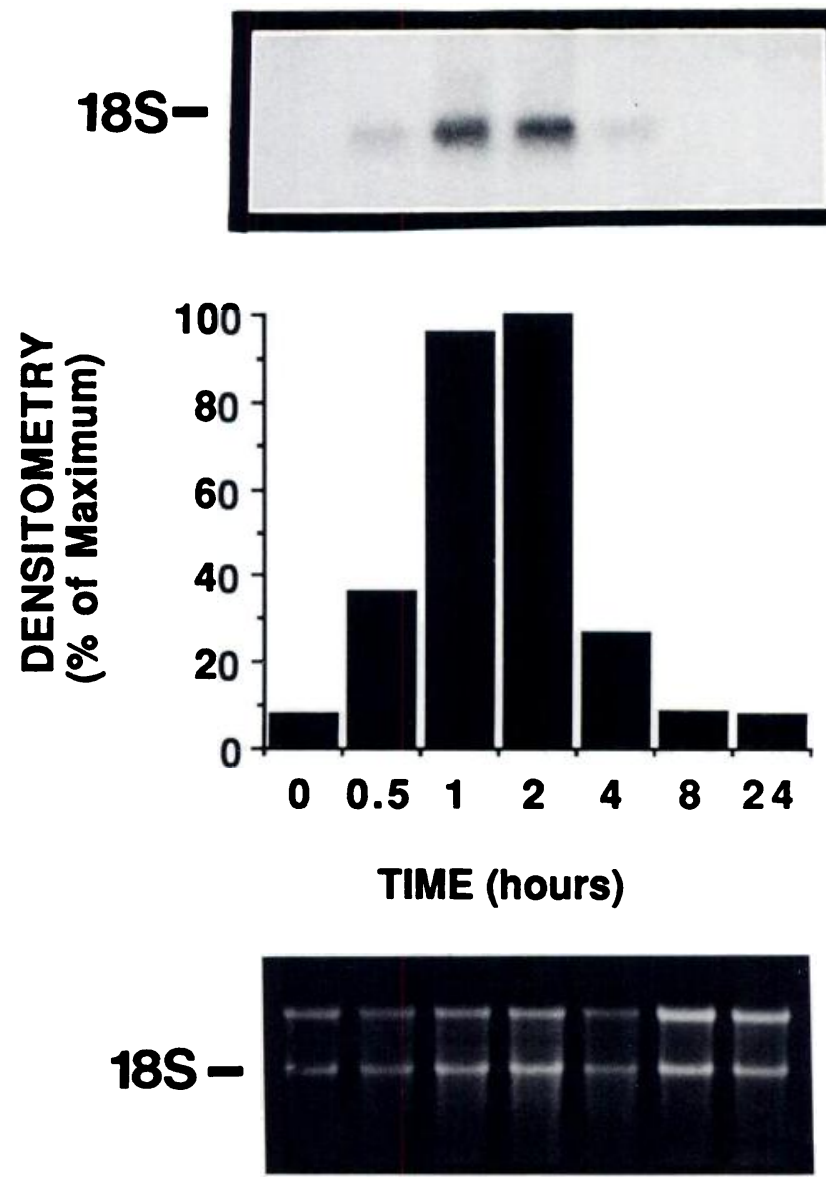

Fig. 2. Northern blot analysis of WB-derived TNF mRNA accumulation. Whole blood was stimulated with LPS $(10 \mu \mathrm{g} / \mathrm{ml})$ and buffy-coat nucleic-acid was extracted in a kinetic fashion. TNF mRNA accumulation was significant at $1 \mathrm{hr}$, peaking at $2 \mathrm{hr}$ post-LPS challenge, and rapidly declined to baseline levels by 8 $h r$. Ten $\mu g$ total RNA was load per lane.

chestrating a variety of local acute and chronic inflammatory processes [1]. The antithesis of local TNF production is its presence systemically, representing an essential mediator of septic shock or chronic cachexia [1]. TNF has been extensively investigated as an important inflammatory protein, yet relatively little is known regarding its synthesis and regulation in human cells. The production of human TNF in vivo has been measured in the serum of septic patients or normal subjects who have received intravenous LPS $[13,14]$. In vitro, both human TNF production and regulation have been evaluated only in cell systems, such as monolayers of blood monocytes or alveolar macrophages [12,15]. A tissue system, simulating the complexity of an in vivo system, would prove useful to assess the dynamics of TNF production and gene expression.

In this present study we demonstrate that intact whole blood can be utilized as a tissue system to examine the

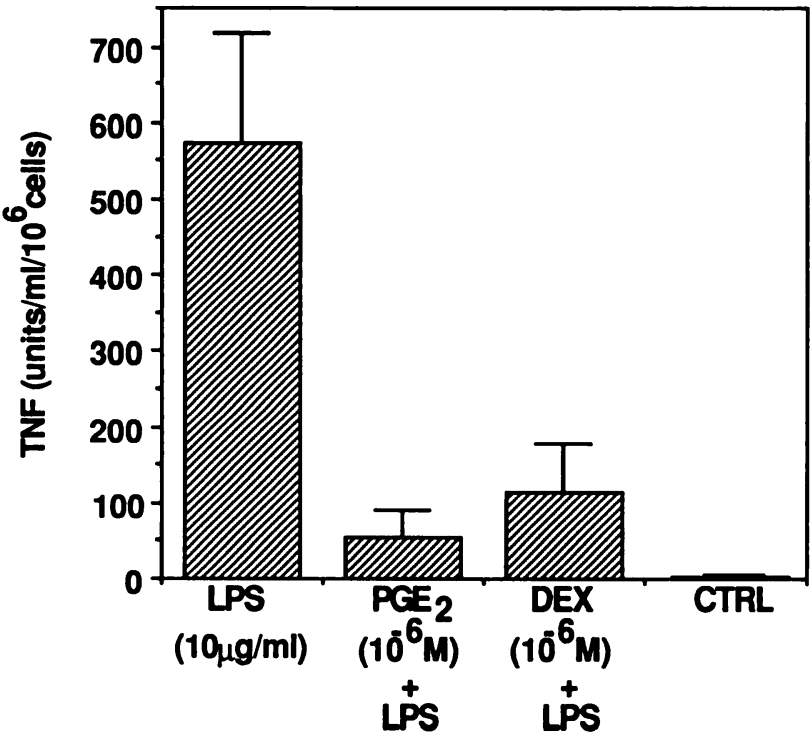

Fig. 3. $\mathrm{PGE}_{2}$ and Dex suppression of LPS-induced TNF bloactivity from WB $(n=3)$. Whole blood was stimulated with elther LPS $(10 \mu \mathrm{g} / \mathrm{ml})$, PGE $_{2}\left(10^{-6} \mathrm{M}\right)$, and LPS $(10 \mu \mathrm{g} / \mathrm{ml})$, or Dex $\left(10^{-6} \mathrm{M}\right)$ and LPS $(10 \mu \mathrm{g} / \mathrm{ml})$ and the plasma analyzed for TNF bioactivity at $3 \mathrm{hr}$. Both $\mathrm{PGE}_{2}$ and Dex demonstrated significant suppression of LPS-induced TNF production $(P<0.05)$.

molecular and cellular expression of TNF. Our findings show that LPS in either a dose-dependent or kinetic fashion results in TNF production from WB. The peak in TNF production from LPS-treated WB was several magnitudes greater than PBM, standardized to equivalent numbers of monocytes. This discrepancy in TNF production between WB and PBM was not explained by lymphocyte-derived TNF, as LPS does not induce the expression of lymphocyte-derived TNF [15]. The peak in WB kinetic expression of TNF was shifted markedly toward the left as compared to PBM. TNF peaked at $4 \mathrm{hr}$ in WB followed by a plateau in activity from 4 to $8 \mathrm{hr}$ and then declined over the next $16 \mathrm{hr}$.

In contrast, the peak in TNF from PBM was delayed until $24 \mathrm{hr}$ post-LPS. The difference in TNF kinetics between WB and PBM was not explained by altered cellular viability, as WB buffy-coat cells and PBM were found to have similar viability at $24 \mathrm{hr}$. The decrease in WB TNF after $8 \mathrm{hr}$ was not due to a WB-derived TNF plasma inhibitor/protease. Plasma isolated from timepoints after $8 \mathrm{hr}$ failed to inhibit exogenous TNF in our bioassay. A plausible explanation for the decline in WB TNF production from 8 to $24 \mathrm{hr}$ may be explained by the internalization of TNF after interaction with its cell-associated receptor [20-22]. In additional studies we demonstrate that both $\mathrm{PGE}_{2}$ and Dex inhibited LPS-induced TNF from WB. This system provides a novel model to determine the efficacy of pharmacologic alteration of cytokines in WB. This aspect is important, since many 
pharmacologic agents are less active in vivo yet retain activity in a less complex system such as cell culture. The use of whole blood as a model system, with the complexity of tissue, has enormous potential for the study of cytokine regulation and synthesis. The cellular and molecular level of cytokine regulation can be studied by monitoring specific mRNA and protein bioactivity in the buffy-coat and plasma, respectively. Furthermore, blood recovered from patients receiving a specific pharmacologic agent can be assessed to determine alterations in both the production of inflammatory cytokines and expression of cytokine mRNA. Regulation of cytokines in whole blood by various substances is relevant and may have significant implication for the use of this system prior to the analysis of drug effects in vivo.

\section{ACKNOWLEDGMENTS}

This work was supported in part by NIH grants DK38149, HL31963, and HL35276. Dr. Steven Kunkel is an Established Investigator of the American Heart Association. The authors thank Dr. Glen Andrews and Henry Showell for the synthesis of oligonucleotides and for helpful discussion. The expert secretarial support of Mrs. Kathleen Atkins is appreciated.

\section{REFERENCES}

1. Beutler, B., and Cerami, A. Cachectin and tumour necrosis factor as two sides of the same biological coin. Nature 320, 584, 1986.

2. Le J., and Vilcek, J. Tumor necrosis factor and interleukin-1: Cytokines with multiple overlapping biological activities. Lab. Invest. 56, 234, 1987.

3. Nawroth, P.P., and Stern, D.M. Modulation of endothelial cell hemostatic properties by tumor necrosis factor. J. Exp. Med. 163, 740, 1986.

4. Pohlman, T.H., Stanness, K.A., Beatty, P.G., Ochs, H.D., and Harlan, J.M. An endothelial cell surface factor(s) induced in vitro by lipopolysaccharide, interleukin-1, and tumor necrosis factoralpha increases neutrophil adherence by a CD-18 dependent mechanism. J. Immunol. 136, 4548, 1986.

5. Le, J., Weinstein, D., Gubler, U., and Vilcek, J. Induction of membrane-associated interleukin-1 by tumor necrosis factor in human fibroblasts. J. Immunol. 138, 2137, 1987.

6. Shalaby, M.R., Aggarwal, B.B., Aindderknecht, E., Svendersky, L.P., Finkle, B.S., and Palladino, A. Jr. Activation of human polymorphonuclear neutrophil functions by interferongamma and tumor necrosis factor. J. Immunol. 135, 2069, 1985.

7. Bachwich, P.R., Chensue, S.W., Larrick, J.W., and Kunkel, S.L. Tumor necrosis factor stimulates interleukin-1 and prosta- glandin $\mathrm{E}_{2}$ production in resting macrophages. Biochem. Biophys. Res. Commun. 136, 94, 1986.

8. Price, S.R., Olivecrona, T., and Pekala, P.H. Regulation of lipoprotein lipase synthesis by recombinant tumor necrosis factorthe primary regulatory role of the hormones in 3T3-L1 adipocytes. Arch. Biochem. Biophys. 251, 738, 1986.

9. Scheurich, P., Thoma, B., Ucer, U., and Pfizenmaier, K. Immunoregulatory activity of recombinant human tumor necrosis factor (TNF)-alpha: Induction of TNF receptors on human T cells and TNF-alpha-mediated enhancement of T cell responses. J. Immunol. 138, 1786, 1987.

10. Tracey, K.J., Beutler, B., Lowry, S.F., Merryweather, J., Wolpe, S., Milsark, I.W., Hariri, R.J., Fahey, T.J., Zentella, A., Albert, J.D., Shires, C.T., and Cerami, A. Shock and tissue injury induced by recombinant human cachectin. Science 234, 470, 1986.

11. Torti, F.M., Diekmann, B., Beutler, B., Cerami, A., and Ringold, G.M. A macrophage factor inhibits adipocyte gene expression: An in vitro model of cachexia. Science 229, 867, 1985.

12. Strieter, R.M., Remick, D.G., Lynch, J.P., Genord, M., Raiford, C., Spengler, R., and Kunkel, S.L. Differential regulation of tumor necrosis factor-alpha in human alveolar macrophages and peripheral blood monocytes: A cellular and molecular analysis. Am. J. Respir. Cell Molec. Biol. 1, 57, 1989.

13. Waage, A., Halstensen, A., and Espevik, T. Association between tumor necrosis factor in serum and fatal outcome in patients with meningococcal disease. Lancet 1, 8529, 1987.

14. Michie, H.R., Manogue, K.R., Spriggs, D.R., Revhaug, A., O'Dwyer, S., Dinarello, C., Cerami, A., Wolff, S.M., and Wilmore, D.W. Detection of circulating tumor necrosis factor after endotoxin adminstration. N. Engl. J. Med. 318, 1481, 1988.

15. Nedwin, G.E., Svedersky, L.P., Bringman, T.S., Palladino, M.A., and Goeddel, D.V. Effect of interleukin-2, interferongamma, and mitogens on the production of tumor necrosis factors alpha and beta. J. Immunol. 135, 2492, 1985.

16. Copenhaver, W.M., Kelly, D.E., and Wood, R.L. Bailey's Textbook of Histology. Baltimore: Williams \& Wilkins, p. 206, 1978.

17. Kunkel, S.L., Spengler, M., May, M.M., Spengler, R., Larrick, J., and Remick, D. Prostaglandin $\mathrm{E}_{2}$ regulates macrophage-derived tumor necrosis factor gene expression. J. Biol. Chem. 263, $5380,1988$.

18. Pennica, D., Nedwin, G.F., and Hayflick, J.S. Human tumor necrosis factor: Precursor structure, expression and homology to lymphotoxin. Nature 312, 724, 1984.

19. Beutler, B., Krochin, N., Milsark, I.W., Luedke, C., and Cerami, A. Control of cachectin (tumor necrosis factor) synthesis: Mechanisms of endotoxin resistance. Science 320, 584, 1986.

20. Ding, A.H., Sanchez, E., Srimal, S., and Nathan, C.F. Macrophages rapidly internalize their tumor necrosis factor receptors in response to bacterial lipopolysaccharide. J. Biol. Chem. 264, $3924,1989$.

21. Imamura, K., Spriggs, D., and Kufe, D. Expression of tumor necrosis factor receptors on human monocytes and internalization of receptor bound ligand. J. Immunol. 139, 2989, 1987.

22. Tsujimoto, M., Yip, Y.K., and Vilcek, J. Tumor necrosis factor: Specific binding and internalization in sensitive and resistant cells. Proc. Natl. Acad. Sci. U.S.A. 82, 7626, 1985. 